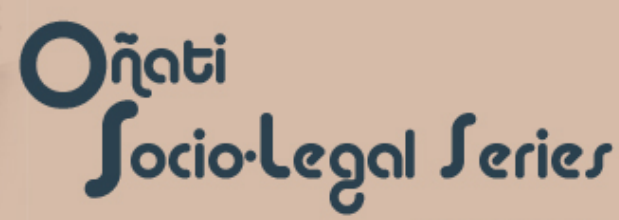

ISSN: 2079-5971

Oñati Socio-legal Series, v. 9, n. 4 (2019) - La institucionalización de la mediación: potencialidades y riesgos

ISSN: 2079-5971

\title{
The I nstitutionalization of Mediation: Reflections from an expert panel
}

\author{
URSULA CASER* \\ NUNO RAMOS*
}

Caser, U., and Ramos, N., 2018. The Institutionalization of Mediation: Reflections from an expert panel. Received 02 January 2018, Accepted 24 May 2018. Oñati Socio-legal Series [online], 9(4), 519-540. Available from: https://doi.org/10.35295/osls.iisl/0000-0000$\underline{0000-1093}$

\begin{abstract}
On 27 and 28 April 2017, the International Institute for the Sociology of Law held a workshop under the theme The Institutionalization of Mediation: Potentialities and Risks. The scientific coordinators of this initiative promoted a structured discussion to identify the risks and potentialities of institutionalization to further develop mediation in the region. This article intends to review some literature supporting the subject of discussions, and to report the intense final discussion within the group of 27 mediation experts (from Germany, Belgium, France, Spain and Portugal). In these final reflections, we do not want to provide definitive answers to burning questions, but we hope to shed a light on the crucial dilemmas as they were discussed in a world-café-like workshop at the end of the meeting. Some limitations and future directions are discussed in light of participatory methods and governance innovation.
\end{abstract}

\section{Key words}

Mediation; institutionalization; collaborative methods; participation; structured discussion format; plurilogue; SWOT workshop

\footnotetext{
* Ursula Caser, CEO of MEDIATEDOMAIN, was born in Germany and lives in Portugal. Her first profession was as a physical geographer. In 2000 she earned a master's degree as a mediator from the European Masters in Mediation Her work focuses on community mediation, public dialogue, consensus building and mediation in complex planning and decision making processes, as well as on training and lecturing in facilitation techniques, conflict management, and general and multiparty mediation, specializing also in intercultural dimensions and communication. She is on the Organization for Security and Cooperation in Europe (OSCE) mediation roster, a delegate for Portugal to the board of the European Mediation Network Initiative (EMNI) and - among others - holds accreditations by the Centre for Effective Dispute Resolution (CEDR), the International Mediation Institute (IMI) and the Portuguese Ministry of J ustice. Contact details: MEDIATEDOMAIN, Lda., Rua Nery Delgado 9-1ㅜ, P-2775-253 Parede, Portugal. Email address: ursula.caser@mediatedomain.com; ORCID: https://orcid.org/0000-0002-3048-6211

* Nuno Ramos is a Psychologist and Mediator, and holds a PhD in Social Psychology on the theme of intercultural competence of conflict mediators, sponsored by a Doctoral Grant (Ref. SFRH/BD/76334/2011) of the Portuguese Science and Technology Foundation. He is member of the Portuguese National Federation of Conflict Mediation, having belonged to the executive board and chaired this institution. He is invited lecturer in ISCTE's Master of Psychology of Intercultural Relations. He has also experience as trainer in the areas of communication, teamwork, change management, and in family and community mediation. Contact details: Centro de Investigação e Intervenção Social, ISCTE-Instituto Universitário de Lisboa, Edf. ISCTE-IUL, Sala 2W17, Avenida das Forças Armadas, 1649-026 Lisboa, Portugal. Email address: nvprs@iscte-iul.pt; ORCID: https://orcid.org/0000-0003-2219-6465
}

\section{(cc) EY-NC-ND}

Oñati International Institute for the Sociology of Law

Antigua Universidad s/n - Apdo.28 20560 Oñati - Gipuzkoa - Spain

Tel. (+34) 943783064

E: opo@iisj.es W: http://opo.iisj.net 


\section{Resumen}

El 27 y 28 de abril de 2017, el Instituto Internacional de Sociología Jurídica organizó un taller sobre el tema La institucionalización de la mediación: potencialidades y riesgos. Los coordinadores científicos de esta iniciativa promovieron una discusión estructurada para identificar los riesgos y potencialidades de la institucionalización para desarrollar aún más la mediación en la región, tema de las discusiones, y para informar la intensa discusión final dentro del grupo de 27 expertos en mediación (de Alemania, Bélgica, Francia, España y Portugal). En estas reflexiones finales, no queremos dar respuestas definitivas a preguntas candentes, pero esperamos arrojar luz sobre los dilemas cruciales tal como fueron discutidos en un taller al estilo de un café mundial al final de la reunión. Las limitaciones y las direcciones futuras se discuten a la luz de los métodos participativos y la innovación de la gobernanza.

\section{Palabras claves}

Mediación; institucionalización; métodos colaborativos; participación; formato de debate estructurado; plurílogo; workshop DAFO 


\section{Table of contents / Índice}

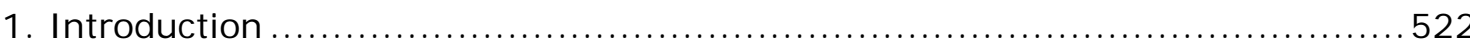

1.1. Identity, ethics, and the development of mediation ........................ 523

1.2. Axe 1-The argument(s) in mediation and its paradox in Europe............524

1.3. Axe 2-The Institutionalization of Mediation as a solution or problem? ...526

2. A proposal for structured discussions........................................ 527

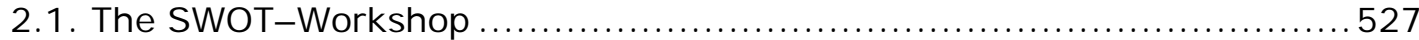

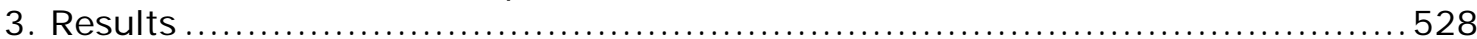

3.1. STRENGTHS of the people / groups that work related to mediation .......528

3.2. WEAKNESSES of the people / groups that work related to mediation ....5529

3.3. THREATS for the institutionalization by external factors ..................5 529

3.4. OPPORTUNITIES for the institutionalization by external factors ...........550

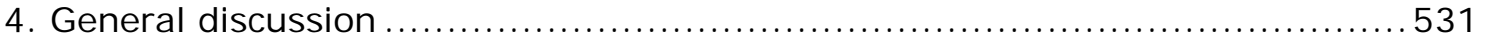

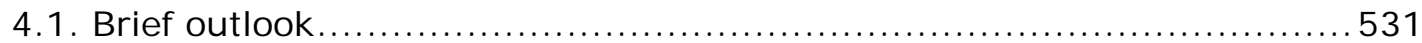

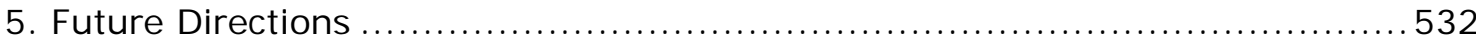

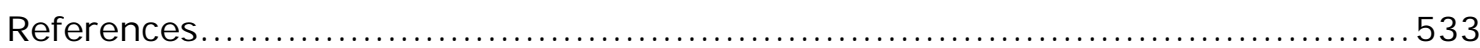




\section{I ntroduction}

In the past 27th and 28th of April, 2017, the International Institute for the Sociology of Law held a workshop under the theme The Institutionalization of Mediation: Potentialities and Risks, coordinated by Alberto J osé Olalde (Facultad de Relaciones Laborales y Trabajo Social - Campus Araba, Universidad del País Vasco/Euskal Herriko Unibertsitatea) and Jacques Faget (Centre Émile Durkheim, Université de Bordeaux). The workshop promoters framed this theme discussion on two major axes. The first relates to the experienced paradox of the mediation growth in regulation and funding throughout Europe, versus its withering practice in some regional areas and intervention contexts. In fact, the increased establishment of public funding and legal provisions for the creation of mediation services, the case expansion from courts derivation, the emergent creation of professional institutions, and proliferation of training, does not render a fully developing practice of mediation. Besides this gap, another axe resides on the implicit tension in dialogue between diverse actors and stakeholders of the field. When considering the institutionalization of mediation as the answer to the previous paradox, the situation produces basic tensions between opposing logics (management solutions versus ethic values), disparity of interests (court, prosecutor's office, lawyers, mediators) and motivations (idealists versus pragmatists). By promoting the debate on a comparative approach from different European countries (Germany, Belgium, France, Spain and Portugal), and diverse intervention focus, the workshop coordinators established a basis to enlighten on the deep contrasts between countries experiences, and promoted a structured discussion to identify the risks and potentialities of institutionalization to further develop mediation in the region.

The starting point of the workshop began with Benoit Bastard (École Normale Supérieure, ENS Paris-Saclay) addressing Mediation as an old innovation. Focusing on mediation in civil and penal matters, Benoit addressed the burning question of which risks are presented by the institutionalization and its dominant organizational constraints (public centralized management or privatization concerns). From his reflections came a word of caution on the potential for the instrumentalization of the process from the judiciary and justice policies, which could hinder "the beautiful idea" of mediation institutionalization, as a way to promote a reasoned negotiation of conflicts (transforming situations, making conflict an opportunity, recognize the changes of situation). In this introductory panel, other experts from the academy world conveyed their views. Nuno Ramos (ISCTE - Instituto Universitário de Lisboa, Federação Nacional de Mediação de Conflitos, FNMC) addressed the challenges of individual and cultural diversity in the institutionalization of the mediation. Gema Varona (Basque Institute of Criminology, University of the Basque Country) offered her reflection on the consequences of the institutionalization of restorative justice services in the Basque context. In the training context of mediation, Isabel Viola (Faculty of Law, University of Barcelona) talked over the infusion of mediation training programs in law curricula in Spain, and Yves Cartuyvels (Université SaintLouis Bruxelles) shared how group research methods can be part of mediation training programs in Belgium.

The debate continued to be moderated by Manel Canyameres (Mediator, Centro Administrativo de Empresas, CADE Consultors, Barcelona) with a focus on the mediator experiences over the institutionalization. Idoia Igartua introduced a reflection on the rhetoric and practice within restorative justice sphere. Miguel Ángel Osma shared some views on his experience as a mediator at the Public Family Mediation Service of Euskadi. Marta Méndez sought to clarify the organizational dynamics and management at the Private Law Mediation Center of the Generalitat de Catalunya. Finally, Jacques Faget summarized his thoughts on the complicated relations between mediation and judicial world.

The panel on the theme Judiciary facing Mediation, moderated by Fernando Espinós, addressed the views of mediation from the perspective of the judiciary. In this 
section, considerations where made from representatives of the judiciary system, such as Ma Concepción Sáez Rodríguez (Spanish General Council of the Judiciary), and judges shared their personal experiences with the process. Antonio Fulleda (Tribunal de Grande Instance de Narbonne, Beziers, France) presented the Narbonne experience on his role of judge as a "pollenisator" of mediation in civil matters. Philippe Bertrand (Court of Appeal of Pau, France) shared his experience from prescribing mediation, and his path from the experimentation of the commercial chamber to the creation of the Judicial Mediation Unit of the Court of Appeal of Pau (France).

\subsection{Identity, ethics, and the development of mediation}

There are many ways to define what mediation is and probably each mediator in practice has its own approach when presenting the process to their clients. One of the broadest approaches is of Della Noce, Bush and Folger (2002) when they call it a "social process in which a third party helps people in conflict understand their situation and decide for themselves what, if anything, to do about it" (Della Noce et al. 2002). Such a simple slogan is embedded of many of the implicit principles that define the distinctiveness of this process. The idea it conveys on the principle of decision-making power seems clear. This third party - the mediator - claims the capacity to facilitate the comprehension of the conflict, however, relinquishes the full responsibility for the decisions on the solutions to the parties. Independently to what specific techniques are used, a mediator focuses on involving parties in a collaborative work towards a solution or agreement, that could be mutually satisfactory, without imposing any solutions or decisions (Della Noce et al. 2002, Kressel 2006, 2014). As an hallmark of practice, a mediator's authority lies within controlling the process whereas the parties are responsible on the composition of issues to address, and over the solutions they achieve (Gibson 1999, Kressel 2014). The major power attribution to the parties in mediation is that it must fully respect their will and self-determination. In fact, informed consent is an ethical foundation for the practice, and to initiate a mediation all parties must express their willingness to participate and that they are not compelled by any force, pressure, or authority (Shapira 2016, 127-162). Throughout the process, a mediator must aspire to a position of neutrality, equidistance and impartiality between the parties, and within each process (Shapira 2016, pp. 271-301 and 207-230). Although the ethical value of mediator neutrality has been criticized, as theoretical and practical literature has demonstrated (Rifkin et al. 1991, Gibson et al. 1996, Taylor 1997, Cohen et al. 1999, Field 2000, Garcia et al. 2003, Mayer 2004, Wing 2009, Izumi 2010, Dyck 2010, Waldman 2011, Bailey 2014), some authors have clarified that equidistance and impartiality are the necessary conditions to achieve neutrality (Mayer 2004, Wing 2009). In fact, Wing (2009) explains that "impartiality is the condition in which a mediator is not taking sides regarding the topic under dispute or the content of any potential agreement, and equidistance is the condition of being equally removed from and remaining unbiased toward each party" (Wing 2009, p. 390).

Another fundamental key to the process success is the rule of confidentiality which promotes privacy, a trustworthy relationship between all participants, and a safe atmosphere to share information (Moore 2014, Shapira 2016, 271-301).

These shared ethical principles may be found throughout the extensive literature on mediation, describing its philosophy and morality (Gibson 1999, Waldman 2011, Shapira 2016, 3-36), theory and common practices (Lande 2000, Wall et al. 2001, Boulle and Nesic 2010, Zariski 2010, Wilson 2010, Wall and Kressel 2012), as in the formal codes of conduct for mediators (Bishop 1984, Cooks and Hale 1994, Taylor 1997, Wilson 2010, Menkel-Meadow 2014, Shapira 2016, 85-126).

Such an ethical framework (Menkel-Meadow et al. 2013, Moore 2014, Shapira 2016, 271-301) legitimizes the mediator role, and intends to promotes the parties' trust over the process. Also, the enumeration of these principles has its purpose of 
demarcating mediation from institutionalized and traditional justice systems channels, as well as other dispute resolution process, such as conciliation, arbitration, and other hybrid solutions (Menkel-Meadow et al. 2013). The discourse of the identity of mediation is described within these ethical assumptions to establish a deontological practice of the mediator, its consequent professionalization, and the quality and integrity of the process (Shapira 2016, especially pp. 231-254). In fact, as Shapira (2016, 3-36) sustains, "[m]ediation must be recognized as a profession, because the field has "special knowledge and skills, autonomy of conduct, commitment to the public, organizational affiliation, and a code of ethics" (Shapira 2016, p. 6). Innumerous codes of conduct have been provided from diverse professional organizations, ONGs, and public institutions (International Mediation Institute n.d., European Commission 2004, American Arbitration Association et al. 2005, Federação Nacional de Mediação de Conflitos 2016). These codes of conduct were designed to develop quality standards of the process, and promote the public trust in mediation as an appropriate and recognized mean for resolving disputes. Following these professional progresses, other legal developments have occurred for the institutionalization and regulation of mediation in Europe, particularly since the Mediation Directive (2008/52/EC), and its additional monitoring reports (Milieu Ltd. 2013, 2016, De Palo et al. 2014, Report from the European Commission COM(2016) 542 final).

Although the identity of mediation have been defined on its ethical grounds and codes of conduct, some have referred this discourse as basis for a mediation mythology (Silbey 1993, 2002) that serve the purpose of an ideological banner to change the paradigm on justice and conflict (Mayer 2004).

Actually, Mediation has developed in a number of interventions contexts, whose practice varies according its target (dyads, groups, or multiparties), focus and level of intervention (Moore 2014). Although we do not intend to list every context we present the major areas of development of theory, intervention, and research:

- Family (Benjamin and Irving 1995, Beck and Sales 2001, Emery et al. 2001, Saposnek 2004, Kelly 2004, Shaw 2010, Parkinson 2014);

- Victim-offender (Umbreit 2001, Umbreit et al. 2004, Zehr 2004);

- Commercial (Esplugues and Marquis 2015)

- Civil mediation (Wissler 2002, 2004, Lande 2004, Charkoudian 2016a, 2016b);

- Business and organizations (Wiseman and Poitras 2002, Bingham 2012, Poitras et al. 2015);

- Education and school peers (Burrell et al. 2003, McWilliam 2010, Cook and Boes 2013);

- Community (Alberts et al. 2005, Neves 2009, Charkoudian 2010, Charkoudian and Bilick 2015);

- Environmental (Emerson et al. 2004, Dukes 2004).

The growth and spread of mediation has accomplished a perspective of its use in conflict resolution in a variety of disputes that was dominated by judicial and adversarial solutions. Mediation is challenging the traditional ways of justice with its innovative movement also needing to become institutionalized as to be sanctioned by courts and government agencies to be accepted by society (Mayer 2004). Underlying this institutionalization is a political framework seeking to cost reduction, and the need for a justice of proximity to address the individual needs of the people, due to the disappointment of traditional justice systems (Menkel-Meadow 2014).

\subsection{Axis 1 - The argument(s) in mediation and its paradox in Europe}

There is a great diversity of factors that motivates people when choosing a conflict resolution process. However, if we consider costs or satisfaction with outcome and 
process fairness, mediation is advocated as a winner in certain contexts. In fact, even compared with arbitration, mediation is less expensive, quicker, and more satisfactory (Brett et al. 1996). Research and mediation advocates have been sustaining that as reasons for choosing mediation are its low costs, quick resolution, and that is one of the more appropriate dispute resolution processes when disputants are motivated towards the maintenance of the parties' relationships and needs of privacy (Kovach 1997, Gale et al. 2002, Charkoudian 2005, Poitras and Le Tareau 2009, Shaw 2010, Wall and Dunne 2012, Kressel 2014, Menkel-Meadow 2016).

Many of the arguments focus on cost reduction and are expressed in more than financial matters. In fact, mediation processes have much lower financial and time burdens to all parties involved when compared to different dispute resolution alternatives (Brett et al. 1996), even if several mediation sessions are considered (De Palo et al. 2014). In addition to the costs on the fees of the experts involved, time of the procedure, there are indirect costs whose measurement is not always taken into account. The adversarial paradigm implies increased personal costs of conflict escalation and a lack of voice from disputants the impacts on the satisfaction process. One common problem of litigation, particularly when parties feel they have lost in an unfair process, is the impact on the outcomes. The possibility of agreements obtained by the judicial process, because third parties impose them, lead to noncompliance and restart the entire judicial process. As Kressel (2014) condenses, client satisfaction, settlement rates, and compliance are among the benefits of mediation. In fact, compliance to settlements from mediation process has proven its long term success (Pruitt et al. 1993, Wall and Dunne 2012). This adherence to the outcomes relates to the parties' responsibilization process following their active participation and empowerment in their conflict resolution (Menkel-Meadow 2014). Thus settlement success is related to the circumstance that the solutions are not imposed by external authorities (Kressel 2014). Menkel-Meadow (2014) has summarized many of the features for the outcome success based on the informality of the mediation process. Mediation allows for solutions that are tailored to the individual interests where there is opportunity to include outcomes that are not rights and claims of law. As positive impact on participant satisfaction with the outcomes are also the inclusion of apologies, the restoration of relationship, or the creativity for other forms of compensations not related to financial arguments (Menkel-Meadow 2014).

In its essence, mediation is acquiring an aura as successful procedure in solving disputes because of its efficiency (reduced time and low costs) and efficacy (the achievement of good outcomes). However, the report Rebooting the Mediation Directive (De Palo et al. 2014) reveals what it calls "the European paradox of mediation". In fact, in the face of a dispute settlement process that has so many benefits, and especially having demonstrated rates of effectiveness around $75 \%$ of the agreement rate, the fact is that their use is around $0.5 \%$ when compared to traditional adversarial processes in a judicial context. That is, mediation is proclaimed as a beneficial, efficient and effective process, however it does not have the expected adhesion.

The market for mediation is still characterized by the increasing number of mediators but few cases and weak earnings. A North American multi-round survey of experienced mediators have already informed on the challenges professionals face when building and managing a private practice (Raines et al. 2013). However, no replication of this study was made solely with mediators from European countries, hence their reality is not known. Our prediction is that although some of these testimonies may be transversal to the practice in Europe, they may certainly bring a much more fragmented view given the variability of the implementation of mediation and legal frameworks in each European country (Milieu Ltd. 2014).

One of the most influential initiatives in the regulation of mediation in Europe was the European Directive of 2008 (2008/52/EC), which initially sought to promote the 
homogenization of the principles of mediation in the context of civil and commercial mediation between member countries' borders. However, the transposition of this Directive into the respective legal frameworks of the Member States has been implemented in very diverse ways and depth, as reflected in the reports on the implementation of the Directive (Milieu Ltd. 2014, 2016, Report from the European Commission).

The implementation of mediation in Europe has resulted in a certain diversity and fragmentation, fundamentally because its development was based on an institutional and governmental will, or from initiatives of NGOs dedicated to its local implementation. As Menkel-Meadow refers, the European legal diversity is one of the factors that might facilitate the promotion or resistance to the implementation of mediation (Menkel-Meadow 2016).

\subsection{Axis 2-The Institutionalization of Mediation as a solution or problem?}

Much of the previous literature on mediation identity comes from a North American point of view since it is historically known as one of the birthplaces for formally recognized processes of mediation. It shows a perspective of mediation based on the need for evidence based research, practice, and evaluation. Nonetheless, from an European stance, Jacques Faget provided an extensive essay on the development and sociopolitical construction of Mediation, its relations between ethical and normative forces, as well as the institutionalization dynamics in each context of intervention (Faget 2010). He concludes with a personal interpretation for the location of each field of mediation intervention between two axes of power dynamics.

In his words, the axis of the system, "distributes mediation practices on a continuum that goes from the forces of the institution to the forces of inspiration" (Faget 2010, p. 276). By the forces of the institution, Faget includes the willingness of the systems to regulate the activity of mediation, with the aim of including these processes in the system itself so as to gain some control over the activity, while benefiting from the potentialities of a process that is characterized by its effectiveness, quick resolution of disputes and low costs. Opposing forces of inspiration focus on the ethical foundations and identity of mediation that assumes a perspective of redistribution of power in justice, as a form of counter-culture against competitive, adversarial processes that are based on hermetic languages and where access to justice and its solutions are regulated by the installed system.

The actor's axis "divides these practices along a continuum that goes from the emancipation of individuals to their normalization" and along the intensity of the devolution of decision-making power to citizens and society at large (Faget 2010, p. 276).

From the dynamics between these axes, a paradoxical situation arises. On the one hand, the forces of institutionalization and normalization intend to integrate the idea of mediation in order to strengthen the process, giving it legitimacy, credibility and enabling an internal resilience. However, these actions may compromise the vision of a process that is ethically bounded, where citizens' free will and creativity are paramount. It may be particularly damaging to the idea of mediation when experimental management decisions make the process mandatory, or constrain the solutions with more directive methods of conflict solving strategies.

Carrie Menkel-Meadow has also addressed this hidden tension that arises from the regulation of mediation, "a tension between individual party choice and control over process and outcome and the need of any legal system to decide when and how the state may intervene in and control the ways in which society's disputes are resolved". (Menkel-Meadow 2016, p. 30). However, as particular factors for resistance to mediation, Menkel-Meadow states that although the diversity on all legal variations is important, "it is the larger social culture, and its interaction with the legal culture, that probably has the greatest impact on the type of dispute resolution methods that 
are chosen in particular societies" (Menkel-Meadow 2016, p. 33). Actually, the perspective of individual and cultural diversity has shown that many variables are at work in conflict resolution procedures (Red Empúries 2014, Ramos and Moleiro 2017).

\section{A proposal for structured discussions}

Since the initial invitation to this workshop, all lecturers were informed that there would be a structured discussion facilitated by Ursula Caser to gather all major reflections from the debate. The facilitator has extensive experience in coordinating multiparty mediation processes, public participation, and in the implementation of collaborative methodologies to promote consensus with various stakeholders. Proposals for methodologies of civic participation and collaboration among diverse groups or individuals with heterogeneity of backgrounds have proven useful for the establishment of more inclusive, integrated, and transparent work agendas and decision making, and literature in this field is vast in proving its beneficial results in a wide range of contexts (Rowe and Frewer 2000, Abelson et al. 2003). These methodologies are especially dedicated to complex issues, where it is necessary to involve people with diverse levels of education, with heterogeneity of disciplinary training, in order to promote transdisciplinary work.

\subsection{The SWOT-Workshop}

The challenge is enormous and the goal of the workshop in Oñati was ambitious: a "distilling" of transversal and transdisciplinary views of the strengths, weaknesses, opportunities and threats of the institutionalization of mediation.

In order to promote a structured SWOT-reflection, a world-café1-type format with four groups was chosen (three homogeneous professional groups - mediators, lawyers and scientists - and one mixed group). The "boundaries" between the groups were, of course, not completely hermetic: some participants were concurrently lawyers and mediators, or college academics and mediators.

IMAGE 1

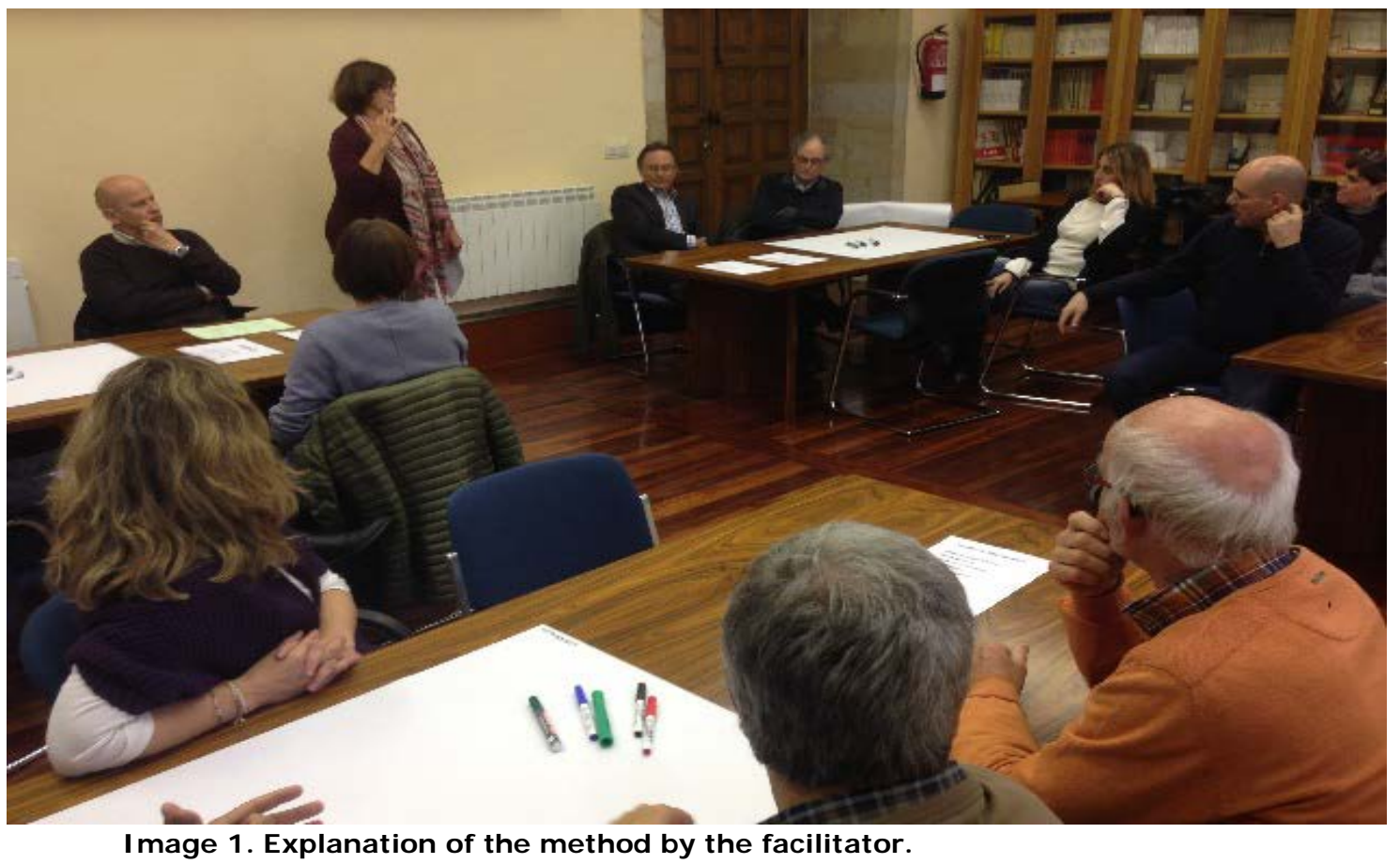

${ }^{1}$ For the exact method see: http://www.worldcafe-europe.net/en/ 
The groups worked on four thematic tables (strengths, weaknesses, threats, opportunities) in four rotations, so each group had the opportunity to work on each topic. None of the group had access to the thoughts and results of their predecessors; they all started every round with a fresh reflection.

\section{IMAGE 2}

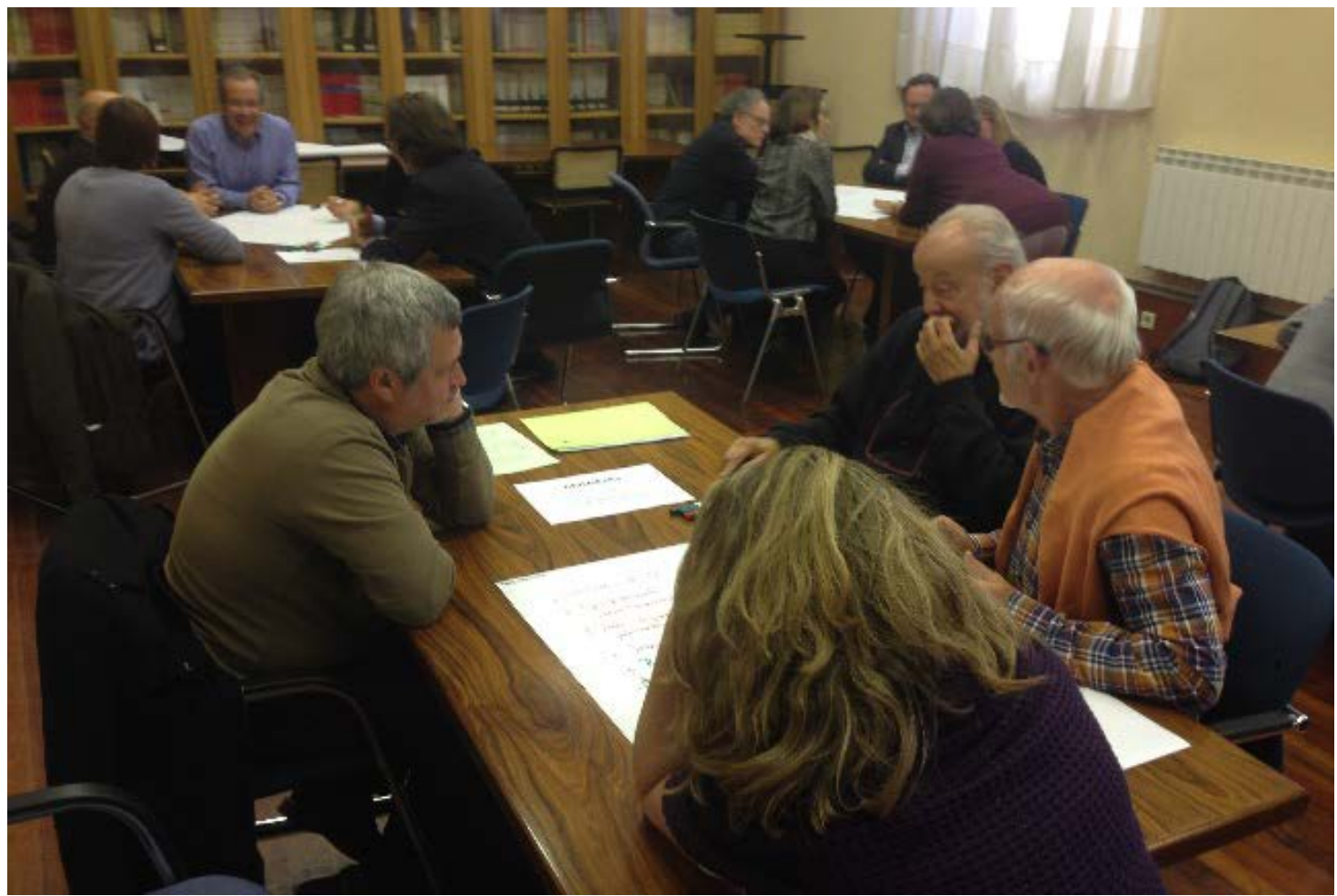

I mage 2. Group discussion at the thematic tables.

STRENGTHS and WEAKNESSES in this exercise meant internal factors of influence: characteristics, attitude and values of the people in the system (mediators, lawyers of all disciplines, academics). The core question here was: What are the characteristics, attitudes, abilities, values and attitudes of the mediators or the members of relevant professional groups that influence the institutionalization of mediation? STRENGTHS foster the institutionalization of mediation and WEAKNESSES hinder them.

THREATS and OPPORTUNITIES explain the external factors (social context, culture, milieu, legal situation, etc.), the academic and juridical "world" and the social atmosphere in which mediation shall be institutionalized. THREATS are, therefore, the effective factors that threaten and endanger the institutionalization of mediation, while OPPORTUNITIES are factors, which tend to favor and promote them.

Each group produced after reflecting on the topic - at its last table - a summary of the results of all previous groups. A general debate followed the presentations of each table's result.

\section{Results}

In the following, we transcribe the results of this reflection, followed by a brief analysis.

\subsection{STRENGTHS of the people / groups that work related to mediation}

- Sustained faith in the culture of peace and consensus;

- Deep conviction of the meaningfulness of mediation and corresponding optimism; 
- Profound understanding of conflict and escalation mechanisms;

- High moral standards (neutrality, respect, courage, fight against discrimination, etc.);

- Cooperative basic (personal and professional), assertiveness and "tenacity";

- Very well developed communication competence (empathy, assertiveness, respect for different thinking, targeted use of communication techniques);

- Willingness to take an active part in the social recognition of the (professional) mediation intervention;

- Deep conviction as to humanistic and democratic values;

- Focus on social values (e.g. the right to access to a structured conflict solution outside the "traditional" justice) ;

- Multidisciplinarity of the mediators as a whole, which opens up a wide range of perspectives;

- Willingness to recognize and defend the limits of institutionalization.

3.2. WEAKNESSES of the people / groups that work related to mediation

- An exaggerated, often unrealistic idealism, which impedes a structured and rigorous institutionalization;

- Nearly exclusive focus on "tangible results" as a result of mediation

- Lack of professional self-esteem regarding the "legitimation" of intervention;

- Financial dependencies and bad pay;

- Lack of awareness / lack of willingness to recognize own basic professional paradigms (lawyer, judge, psychologist, pastor, etc.) and to change it in favor of the mediation paradigm when intervening as a mediator;

- Fear of professional dependency and loss of freedom;

- Prejudice, jealousy and mistrust of colleagues and relevant professional groups as well as by political and legal spheres of influence;

- Strong competitive thinking and behavior between colleagues and professional groups (especially in the "training market");

- Conceptual disagreements;

- Rejection of internal and external evaluation and supervision of the own mediation intervention;

- Disability to resolve conflicts between professional groups and associations or lack of willingness to self-organized and consensus oriented cooperation in associations;

- Resistance to promote an intense lobbying;

- Inadequate humanistic, methodological and interdisciplinary training of mediators and consequently a generalized lack of intervention competence;

- Anxiety for protection of the profession and aspiration of legislative security.

\subsection{THREATS for the institutionalization by external factors}

- The "culture of confrontation" is socially dominant; very competitive society;

- Hybrid concept of mediation leads to poor "explicability" and consequently the process is badly understood by potential users;

- Narcissism and (aspired) leadership of the legal system and the professional groups (attorneys, judges, civil servants, etc.) that operate the legal system. They see their "authority" (and their business model) threatened by mediation;

- The efforts of the relevant authorities and the legal system as a whole intending to control the "new" professional group and its intervention; 
- Open or covert opposition, as well as systemic immobility of legal and social systems;

- Difficulty to bring normative discourse (inflexible and rigid) in cover with mediation practices (individualized and flexible) ;

- Inefficient legislation, legislation and norms;

- The fast-paced nature of the current society promotes the search for fast solutions;

- Lack of financial support/funding;

- Lack of demand from civil society/enterprises/organizations, etc. (paradox of mediation);

- Inadequate structural mechanisms in the state's conflict resolution system (also mediation in the court does not help here);

- Weak social recognition of the mediator and mediation.

\subsection{OPPORTUNITIES for the institutionalization by external factors}

- Existence of the European Directive and relevant national legislation in all European countries;

- Existence of European and national research programs to explore mediation and its overall social impact (open up possibilities for financing);

- Scientific evidence of the suitability of mediation for consensus oriented conflict resolution exists meanwhile in many areas;

- Proven economic profitability of mediation with regard to financial, personnel and temporal resources;

- Social demands / pressure to establish new models for conflict resolution;

- The contemporary "Shared Power World", which is characterized by complex questions, requires new methods of conflict regulation;

- The notable World- and Europe-wide increase in conflicts;

- An increasingly articulated claim for participation, involvement in decisions and co-creation by civil society;

- The resurgence of religion and peace-minded spirituality favors a more consensus oriented attitude of mind, as well as promotes the "willingness to negotiate";

- The increasing inclusion of communication competences and consensus oriented conflict resolution methods in school curricula (social curricula, student editors, etc.);

- Mediation is often faster and cheaper than a court process which - moreover - may have an uncertain outcome;

- Increasing disappointment and frustration of legal professional groups with regard to the efficiency of legislation as well as to the legal processes and their results;

- Dwindling confidence/decreasing satisfaction of the civil society with regard to the efficiency of legislation as well as to the legal processes and their results;

- Increasing political readiness to tackle the decentralization of the State and its interventions;

- Increased credibility of mediation through good experiences (national and international);

- Development of ethical guidelines and best practice on a national and international level;

- The willingness of mediator associations to standardize the training and certification of mediators across all fields of application. 


\section{General discussion}

These results show that the institutionalization of mediation is driven by a complex set of specific conditions in the field with an additional and quite complex dynamic. The discussion including the multi-mediation field perspectives and deeply rooted practical experience of the participants proved that even the concept of institutionalization is not homogeneous between them.

In our more and more individualized society, reflexive mediations seem to be on withdrawal or at least in stagnation. This may promote hybrid processes like semi directive methodologies and negotiations that are assisted or even controlled by law professionals. There are many threats out there: Internal mediations are growing but there is no clue so far how this influences the principles of mediation; the justice system takes over and instrumentalizes and manipulates the idea of mediation.

Mediators move in an oral world, a lawyer writes and tells stories in a written way whereas mediators make other people talk. There is a radical difference between these worlds.

In general and for the future, we can deduct that there is no clear prognosis. For simple conflicts (commercial), hybrid mediators may dominate the market, nearly without control of quality. On the other hand reflexive mediations will continue, because there is still a lot of motivation and situations out there that demand for sensitive transformative interventions.

The crucial problem is that people look for quick receipt like processes and solutions and do not know what mediation is and therefore cannot look for it.

\subsection{Brief outlook}

To the participating authors' opinion, for a satisfactory institutionalization of mediation in Europe three challenges must be overcome:

Firstly, the lack of cooperation between European mediators. Aside from EMNI, the European Mediation Network Initiative (working badly), there is no European association or federation in which we could all join in organizing ourselves, defending our interests and making ourselves heard. The world is increasingly conflictive and so are we. When we will really be interested in each other? We need to speak with "one voice" and make political pressure. Lobbying is urgently needed!

Secondly, the mediation trainings are very different all over Europe, regarding focus, length and quality. In France, a recognized training for family mediator takes three years and includes up to 560 hours of theory and at least 70 hours of practice. In Great Britain one can be described as a "certified economic mediator" with 40 hours in a week - compactly completed training and after evaluation of competences (though by the training institute itself) -. This variability, without a Europe-wide classification, in combination with the large range of origin of professions, results in a distinctly hybrid colleague field. Not surprisingly, the market for mediation in this context is so weakly developed in practically all European countries.

Thirdly, there is a tangible competition among the mediators. Too many mediators think they practice the "right" mediation. Ideological trenches poison the - so necessary - solidarity between colleagues. "Active" mediation versus "passive" mediation, "Harvard disciples" versus "transformers", commitment to mediation against voluntariness, voluntariness versus willingness to try a mediation, etc. The conflicts are manifold and often not resolved. We even do not meet and exchange our ideas regularly. Most congresses are still rooted (at least in the parallel sessions) either in the Germanic (German, English, Scandinavian...) or the Romance language area (French, Italian, Spanish, and Portuguese). Where is the constructive debate, the mediation between mediators? 


\section{Future Directions}

This workshop provided a first step towards the identification of some aspects already mentioned in the literature and research. It will be important to consider the results of this group reflection as a starting point for future discussions.

On the one hand, the great diversity of areas of expertise and intervention context of these workshop participants promotes greater wealth for the focus on the transversal aspects of the various areas of mediation. However, it would be important to consider similar initiatives that could address the challenges of institutionalization within the specific sensitivities of each mediation context (civil, commercial, family, criminal, etc.), and by the inclusion of other participants that could convey the realities of other European countries. On the other hand, this methodology has generically identified the strengths, weaknesses, opportunities and threats for a beneficial development of the institutionalization of mediation. As a proposal for the continuity of this work, we suggest the promotion of other collaborative initiatives that could allow the exploration of the emerging themes of this SWOT analysis, with a focus on seeking resolutions to enhance the strategic development of mediation. Thus, specific solutions and proposals for action should be addressed to strengthen forces and seize opportunities, recover weaknesses and reduce the impact of the identified threats, as well as by the implementation of other types of consensusbuilding methodologies.

However, there is a need for more exploration, as it does not appear to have been analyzed all possible dimensions and factors, and saturation of contents could still be achieved by other methods and research designs. From a top-down perspective, considering the knowledge of experts, policy makers and major stakeholders, other types of consensus-building methodologies could be beneficial. A Delphi methodology might be useful at clarifying certain fragmented definitions, or forecasting on future trends or unexplored areas of knowledge. The Delphi technique is a consensusbuilding process to achieve a convergence of opinion on a complex issue, using a series of iterative questionnaires to collect data from a panel of selected experts (Hasson et al. 2000, Linstone and Turoff 2002, Mullen 2003, Okoli and Pawlowski 2004, Hsu and Sandford 2007, Grisham 2009). From a bottom-up approach, literature has widely referred the importance of the participation of citizens, where consultative, participatory and deliberative approaches may promote better interaction between decision makers and the public. There are many proposals for this type of techniques (Rowe and Frewer 2000), where deliberative methods where systematic reviewed in the health sector (Abelson et al. 2003).

The possibility of multidisciplinary and interregional debate has proven to be proficuous in order to reach an interdisciplinary vision, of synthesis of the different knowledge, with a holistic vision, and that tend to promote more integrative and transversal solutions. Assuming "mediation as an old innovation", as Benoit Bastard stated in the beginning of the workshop, it could be useful to consider the proposal of Stilgoe and colleagues in their framework for a responsible research and innovation (Stilgoe et al. 2013). After defining a prospective model of responsibility, they describe four integrated dimensions of responsible innovation: anticipation, reflexivity, inclusion and responsiveness (see Stilgoe et al. 2013 for an extended review on these concepts). Although the authors' case study is from the geoengineering field, crossing boundaries of science and technology, their model of responsible innovation might have a more general application and relevance to other interdisciplinary fields. As new emergent technologies have few agreed structures or rules that govern them, so did mediation in the past. The problem posed by the institutionalization of mediation is that it implies a step back in governance, policymaking and regulatory efforts. The European Union, within its decision-making institutions concerning justice and conflict resolution, should view the innovation of mediation in a more responsible way. Following Stilgoe and colleagues' (2013) framework, European institutions should promote systematic thinking aimed at 
increasing strength of the process but having the plasticity to allow new opportunities for innovation (anticipation). Institutional practice, although tendentially resistant to anticipate, should be aware that its assumptions or framing of certain issues may not be universal, and the diversity of perspectives outside of the institutional field might frustrate the programmed activities and commitments (reflexivity). Actually, the more innovative governance practices have acknowledge that policy-making should not depend exclusively on experts and top-down process, but also foster the integration of citizens and stakeholders at the deliberative core of governance (inclusion). And finally, innovative responsible institutions should be capable of changing its structure or programmatic direction if stakeholder, public values or changing circumstances demands so (responsiveness).

However, mediators, and mediation advocates, could also learn from the line of questioning on responsible innovation. As Kressel (2014) points out, the mediation field has held the burden of proof on its merits, hence it is not surprising the amount of research done in process evaluation and outcome assessment. Unquestionably, mediation in Europe there is still a long path to walk in this area. However, the opportunity lies in the possibility of structuring a European vision for mediation research, intervention and policymaking. Within the community mediation centers in the USA, which rely on multiple public and private resources to provide mediation services, it has been suggested that board diversity and representativeness could positively impact the organizational effectiveness and the achievement of their programmatic objectives, as it may offer an additional source of collaborative capacity (Gazley et al. 2010).

A final word comes to congratulate the coordinators, Alberto J osé Olalde and Jacques Faget, and also the moderators and participants of the workshop The Institutionalization of Mediation: Potentialities and Risks. The enthusiastic debate that was fostered and the generosity in their shared experiences, showed their passion for the field of mediation. We hope that the reflections summarized in this article can engage others in participating in future debates and discussions that will certainly take place. Mediators need to meet, to exchange and discuss ideas, to learn more about each other. Mediators need to fight for "a common mediation" regardless ideologies, language boundaries, and competitive thinking.

\section{References}

Abelson, J., et al., 2003. Deliberations about deliberative methods: Issues in the design and evaluation of public participation processes. Social Science and Medicine [online], 57(2), pp. 239-251. Available from: https://www.ncbi.nlm.nih.gov/pubmed/12765705 [Accessed 28 September 2018].

Alberts, J.K., Heisterkamp, B.L., and McPhee, R.M., 2005. Disputant perceptions of and satisfaction with a community mediation program. International Journal of Conflict Management [online], 16(3), pp. 218-244. Available from: https://doi.org/10.1108/eb022930 [Accessed 28 September 2018].

American Arbitration Association and American Bar Association and Association for Conflict Resolution, 2005. The Model Standards of Conduct for Mediators [online]. September. Available from:

https://www.adr.org/sites/default/files/document_repository/AAA\%20Mediato rs\% 20Model\% 20Standards\% 20of\% 20Conduct\% 2010.14.2010.pdf [Accessed 28 September 2018].

Bailey, P., 2014. Neutrality in mediation: an ambiguous ethical value. Journal of Mediation \& Applied Conflict Analysis [online], 1(1), pp. 53-56. Available from: http://kennedyinstitute. nuim.ie/journal-of-mediation-and-applied-conflictanalysis [Accessed 28 September 2018]. 
Beck, C.J.A., and Sales, B.D., 2001. Future mediation research. In: The Law and Public Policy. Family Mediation: Facts, Myths, and Future Prospects [online]. Washington, DC: American Psychological Association, pp. 125-166. Available from: http://doi.org/10.1037/10401-009 [Accessed 28 September 2018].

Benjamin, M., and Irving, H.H., 1995. Research in family mediation: Review and implications. Mediation Quarterly [online], 13(1), pp. 53-82. Available from: https://doi.org/10.1002/crq.3900130107 [Accessed 28 September 2018].

Bingham, L.B., 2012. Transformative Mediation at the United States Postal Service. Negotiation and Conflict Management Research [online], 5(4), pp. 354-366. Available from: http://doi. wiley.com/10.1111/i.1750-4716.2012.00112.x [Accessed 28 September 2018].

Bishop, T.A., 1984. Mediation standards: an ethical safety net. Conflict Resolution Quarterly [online], 1984(4), pp. 5-17. Available from: http://doi.wiley.com/10.1002/cra [Accessed 28 September 2018].

Boulle, L., and Nesic, M., 2010. Mediator Skills and Techniques: Triangle of Influence. Haywards Heath: Bloomsbury Professional.

Brett, J.M., Barsness, Z.L., and Goldberg, S.B., 1996. The Effectiveness of Mediation: An Independent Analysis of Cases Handled by Four Major Service Providers. Negotiation Journal [online], 12(3), pp. 259-269. Available from: https://doi.org/10.1111/j.1571-9979.1996.tb00099.x [Accessed 28 September 2018].

Burrell, N.A., Zirbel, C.S., and Allen, M., 2003. Evaluating peer mediation outcomes in educational settings: A meta-analytic review. Conflict Resolution Quarterly [online], 21(1), pp. 7-26. Available from: http://doi.wiley.com/10.1002/crq.46 [Accessed 28 September 2018].

Charkoudian, L., 2005. A Quantitative Analysis of the Effectiveness of Community Mediation in Decreasing Repeat Police Calls for Service. Conflict Resolution Quarterly [online], 23(1), pp. 87-98. Available from: https://doi.org/10.1002/crq.126 [Accessed 28 September 2018].

Charkoudian, L., 2010. Giving Police and Courts a Break: The Effect of Community Mediation on Decreasing the Use of Police and Court Resources. Conflict Resolution Quarterly [online], 28(2), pp. 141-155. Available from: https://doi.org/10.1002/crq.20017 [Accessed 28 September 2018].

Charkoudian, L., 2016a. Impact of Alternative Dispute Resolution on Responsibility, Empowerment, Resolution, and Satisfaction with the Judiciary: Comparison of Short- and Long-Term Outcomes in District Court Civil Cases [online]. Report. Prepared for the State J ustice Institute and Maryland J udiciary. Annapolis: Maryland Administrative Office of the Courts, February. Available from: http://mdmediation. org/sites/default/files/Impact of District Court DOT ADR.pdf [Accessed 28 September 2018].

Charkoudian, L., 2016b. What Works in District Court Day of Trial Mediation: Effectiveness of Various Mediation Strategies on Short-and Long-Term Outcomes [online]. Report. Prepared for the State Justice Institute and Maryland Judiciary. Annapolis: Maryland Administrative Office of the Courts, J anuary. Available from: http://mdmediation.org/sites/default/files/What Works in District Court DOT Mediation.pdf [Accessed 28 September 2018].

Charkoudian, L., and Bilick, M., 2015. State of Knowledge: Community Mediation at a Crossroads. Conflict Resolution Quarterly [online], 32(3), pp. 233-276. Available from: http://doi. wiley.com/10.1002/crq.21112 [Accessed 28 September 2018]. 
Cohen, O., Dattner, N., and Luxenburg, A., 1999. The limits of the mediator's neutrality. Mediation Quarterly [online], 16(4), pp. 341-348. Available from: http://doi.wiley.com/10.1002/crq.3900160404 [Accessed 28 September 2018].

Cook, J.Y., and Boes, S.R., 2013. Mediation Works: An Action Research Study Evaluating the Peer Mediation Program from the Eyes of Mediators and Faculty [online]. Available from: https://files.eric.ed.gov/fulltext/ED547782.pdf [Accessed 28 September 2018].

Cooks, L.M., and Hale, C.L., 1994. The construction of ethics in mediation. Mediation Quarterly [online], 12(1), pp. 55-76. Available from: https://doi.org/10.1002/crq.3900120106 [Accessed 28 September 2018].

De Palo, G., et al., 2014. "Rebooting" the mediation directive: Assessing the limited impact of its implementation and proposing measures to increase the number of mediations in the EU, Brussels [online]. Study. Brussels: European Parliament, J anuary. Available from:

http://www.europarl.europa.eu/RegData/etudes/etudes/join/2014/493042/IP OL-JURI_ET(2014)493042_EN.pdf [Accessed 28 September 2018].

Della Noce, D.J., Bush, R.A.B., and Folger, J.P., 2002. Clarifying the Theoretical Underpinnings of Mediation: Implications for Practice and Policy. Pepperdine Dispute Resolution Law Journal [online], 3(1), pp. 39-65. Available from: https://scholarlycommons. law. hofstra. edu/faculty scholarship/163 [Accessed 28 September 2018].

Directive 2008/52/EC of the European Parliament and of the Council of 21 May 2008 on certain aspects of mediation in civil and commercial matters. Official J ournal of the European Union [online], L 163/3, of 24 May 2008. Available from: http://eur-lex.europa.eu/legal-content/en/ALL/?uri=CELEX: 32008 L0052 [Accessed 28 September 2018].

Dukes, E.F., 2004. What we know about environmental conflict resolution: An analysis based on research. Conflict Resolution Quarterly [online], 22(1-2), pp. 191-220. Available from: https://doi.org/10.1002/crq.98 [Accessed 28 September 2018].

Dyck, D., 2010. The mediator as nonviolent advocate: Revisiting the question of mediator neutrality. Conflict Resolution Quarterly [online], 18(2), pp. 129149. Available from: https://doi.org/10.1002/crq.3890180204 [Accessed 28 September 2018].

Emerson, K., O'Leary, R., and Bingham, L.B., 2004. Commentary: Comment on Frank Dukes's "what we know about environmental conflict resolution". Conflict Resolution Quarterly [online], 22(1-2), pp. 221-231. Available from: https://doi.org/10.1002/crq.99 [Accessed 28 September 2018].

Emery, R.E., et al., 2001. Child custody mediation and litigation: Custody, contact, and coparenting 12 years after initial dispute resolution. Journal of Consulting and Clinical Psychology [online], 69(2), 323-332. Available from: http://doi.org/10.1037/0022-006X.69.2.323 [Accessed 28 September 2018].

Esplugues, C., and Marquis, L., eds., 2015. New Developments in Civil and Commercial Mediation Global Comparative Perspectives. Heidelberg: Springer.

European Commission, 2004. European code of conduct for mediators [online]. Available from:

http://ec.europa.eu/civiljustice/adr/adr_ec_code_conduct_en.pdf [Accessed 28 September 2018].

Faget, J., 2010. Médiations : Les ateliers silencieux de la démocratie. Toulouse: Érès. 
Federação Nacional de Mediação de Conflitos, 2016. Código de deontologia e boas práticas do mediador de conflitos da Federação Nacional de Mediação de Conflitos [online]. Available from: http://www.fnmc.pt/docs/codigodeontologia-fnmc.pdf [Accessed 28 September 2018].

Field, R., 2000. Neutrality and power: myths and reality. ADR Bulletin [online], 3(1). Available from: https://epublications.bond.edu.au/adr/vol3/issl/4 [Accessed 28 September 2018].

Gale, J., et al., 2002. Considering effective divorce mediation: three potential factors. Conflict Resolution Quarterly [online], 19(4), pp. 389-420. Available from: https://doi.org/10.1002/crq.3890190403 [Accessed 28 September 2018].

Garcia, A.C., Vise, K., and Whitaker, S.P., 2003. Disputing neutrality: A case study of a bias complaint during mediation. Conflict Resolution Quarterly [online], 20(2), pp. 205-230. Available from: https://doi.org/10.1002/crq.20 [Accessed 28 September 2018].

Gazley, B., Chang, W.K., and Bingham, L.B., 2010. Board diversity, stakeholder representation, and collaborative performance in community mediation centers. Public Administration Review [online], 70(4), pp. 610-620. Available from: https://doi.org/10.1111/j.1540-6210.2010.02182.x [Accessed 28 September 2018].

Gibson, K., 1999. Mediator attitudes toward outcomes: A philosophical view. Mediation Quarterly [online], 17(2), pp. 197-211. Available from: https://doi.org/10.1002/crq.3890170209 [Accessed 28 September 2018].

Gibson, K., Thompson, L., and Bazerman, M.H., 1996. Shortcomings of Neutrality in Mediation: Solutions Based on Rationality. Negotiation Journal [online], 12(1), pp. 69-80. Available from: http://doi. wiley.com/10.1111/j.15719979.1996.tb00079.x [Accessed 28 September 2018].

Grisham, T., 2009. The Delphi technique: a method for testing complex and multifaceted topics. International J ournal of Managing Projects in Business [online], 2(1), pp. 112-130. Available from: http://doi.org/10.1108/17538370910930545 [Accessed 28 September 2018].

Hasson, F., Keeney, S., and McKenna, H., 2000. Research guidelines for the Delphi survey technique. Journal of Advanced Nursing [online], 32(4), pp. 10081015. Available from: https://doi.org/10.1046/j.1365-2648.2000.t01-101567.x [Accessed 28 September 2018].

Hsu, C., and Sandford, B.A., 2007. The Delphi Technique: Practical assessment, research and evaluation [online], 12(10). Available from: https://pareonline.net/pdf/v12n10.pdf [Accessed 28 September 2018].

International Mediation Institute, n.d. Code of Professional Conduct [online]. The Hague: International Mediation Institute. Available from: https://imimediation.org/imi-code-of-professional-conduct [Accessed 28 September 2018].

Izumi, C., 2010. Implicit Bias and the Illusion of Mediator Neutrality. Washington University Journal of Law and Policy [online], 34(71), pp. 71-156. Available from: http://repository.uchastings.edu/faculty_scholarship/282 [Accessed 28 September 2018].

Kelly, J.B., 2004. Family mediation research: Is there empirical support for the field? Conflict Resolution Quarterly [online], 22(1-2. Special Issue: Conflict Resolution in the Field: Assessing the Past, Charting the Future), pp. 3-35. Available from: https://doi.org/10.1002/crq. 90 [Accessed 28 September 2018]. 
Kovach, K.K., 1997. Costs of Mediation: Whose Responsibility? Mediation Quarterly [online], 15(1), pp. 13-27. Available from:

https://doi.org/10.1002/crq. 3900150104 [Accessed 28 September 2018].

Kressel, K., 2006. Mediation revisited. In: M. Deutsch, P.T. Coleman and E.C. Marcus, eds., The Handbook of Conflict Resolution: Theory and Practice. $2^{\text {nd }}$ revised ed. San Francisco, CA: Jossey-Bass, pp. 726-756.

Kressel, K., 2014. The mediation of conflict: context, cognition, and practice. In: M. Deutsch, P.T. Coleman and E.C. Marcus, eds., The Handbook of Conflict Resolution: Theory and Practice. $3^{\text {rd }}$ ed. San Francisco, CA: Jossey-Bass, pp. 817-848.

Lande, J., 2000. Toward More Sophisticated Mediation Theory. Journal of Dispute Resolution [online], 2000, p. 321. Available from:

https://heinonline.org/HOL/LandingPage?handle=hein.journals/jdisres2000\&di

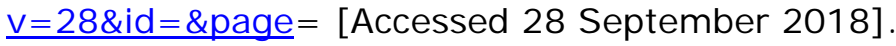

Lande, J., 2004. Commentary: Focusing on Program Design Issues in Future Research on Court-Connected Mediation. Conflict Resolution Quarterly [online], 22(1), pp. 89-101. Available from: https://doi.org/10.1002/crq.93 [Accessed 28 September 2018].

Linstone, H.A., and Turoff, M., 2002. The Delphi Method: Techniques and applications [online], pp. 1-616. Available from:

https://web. njit. edu/ turoff/pubs/delphibook/delphibook.pdf [Accessed 28 September 2018].

Mayer, B.S., 2004. Beyond Neutrality: Confronting the Crisis in Conflict Resolution. San Francisco, CA: Jossey-Bass.

McWilliam, N., 2010. A school peer mediation program as a context for exploring therapeutic jurisprudence ( $\mathrm{TJ})$ : Can a peer mediation program inform the law? International journal of law and psychiatry [online], 33(5-6), pp. 293-305. Available from: https://doi.org/10.1016/j.ijlp.2010.09.002 [Accessed 28 September 2018].

Menkel-Meadow, C., 2014. Alternative and Appropriate Dispute Resolution in Context Formal, Informal, and Semiformal Legal Processes. In: M. Deutsch, P.T. Coleman and E.C. Marcus, eds., The Handbook of Conflict Resolution: Theory and Practice. $3^{\text {rd }}$ ed. San Francisco, CA: Jossey-Bass.

Menkel-Meadow, C., 2016. The Future of Mediation Worldwide: Legal and Cultural Variations in the Uptake of or Resistance to Mediation. In: I. Macduff, ed., Essays on Mediation Dealing with Disputes in the 21st Century. Alphen aan den Rijn: Wolters Kluwer Law International, pp. 29-46.

Menkel-Meadow, C., Love, L.P., and Schneider, A.K., 2013. Mediation: Practice, Policy, and Ethics. $2^{\text {nd }}$ ed. Alphen aan den Rijn: Wolters Kluwer Law \& Business.

Milieu Ltd., 2014. Study for an evaluation and implementation of Directive 2008/52/EC - the "Mediation Directive" [online]. Final report, October. Prepared for the European Commission. Luxembourg: Publications Office of the European Union. Available from: https://publications. europa. eu/en/publication-detail/-/publication/bba3871d223b-11e6-86d0-01aa75ed71a1/ [Accessed 28 September 2018].

Milieu Ltd., 2016. Study for an evaluation and implementation of Directive 2008/52/EC - the "Mediation Directive" [online]. Final report, updated 16 March. Prepared for the European Commission. Luxembourg: Publications Office of the European Union. Available from: 
https://publications.europa.eu/en/publication-detail/-/publication/bba3871d223b-11e6-86d0-01aa75ed71a1/language-en [Accessed 28 September 2018].

Moore, C.W., 2014. The Mediation Process: Practical Strategies for Resolving Conflict. $4^{\text {th }}$ ed. San Francisco, CA: Jossey-Bass.

Mullen, P.M., 2003. Delphi: myths and reality. Journal of Health Organization and Management [online], 17(1), pp. 37-52. Available from: https://doi.org/10.1108/14777260310469319 [Accessed 28 September 2018].

Neves, T., 2009. Practice Note: Community Mediation as Social Intervention. Conflict Resolution Quarterly [online], 26(4), pp. 481-496. Available from: https://doi.org/10.1002/crq.244 [Accessed 28 September 2018].

Okoli, C., and Pawlowski, S.D., 2004. The Delphi method as a research tool: an example, design considerations and applications. Information \& Management [online], 42(1), pp. 15-29. Available from:

http://dx.doi.org/10.1016/j.im.2003.11.002 [Accessed 28 September 2018].

Parkinson, L., 2014. Family Mediation. $3^{\text {rd }}$ ed. Bristol: Family Law.

Poitras, J., and Le Tareau, A., 2009. Quantifying the Quality of Mediation Agreements. Negotiation and Conflict Management Research [online], 2(4), pp. 363-380. Available from: https://doi.org/10.1111/j.17504716.2009.00045.x [Accessed 28 September 2018].

Poitras, J., et al., 2015. Managerial mediation competency: A mixed-method study. Negotiation Journal [online], 31(2), pp. 105-129. Available from: https://doi.org/10.1111/nejo.12085 [Accessed 28 September 2018].

Pruitt, D.G., et al., 1993. Long-term success in mediation. Law and Human Behavior [online], 17(3), pp. 313-330. Available from: http://doi.apa.org/getdoi.cfm?doi=10.1007/BF01044511 [Accessed 28 September 2018].

Raines, S.S., Pokhrel, S.K., and Poitras, J., 2013. Mediation as a Profession: Challenges That Professional Mediators Face. Conflict Resolution Quarterly [online], 31(3), pp. 79-97. Available from: https://doi.org/10.1002/crq.21080 [Accessed 28 September 2018].

Ramos, N., and Moleiro, C., 2017. Intercultural Challenges in Conflict Mediation. In: A. Thomas, ed., Cultural and Ethnic Diversity: How European Psychologists can Meet the Challenges. Göttingen: Hogrefe, pp. 87-92.

Red Empúries, 2014. Aspectos pertinentes de la conceptualización de la mediación: perspectivas anglo-sajona y latina. La Trama [online], 42. Retrieved from http://www. revistalatrama.com.ar/contenidos/larevista_articulo. php?id=290\& ed=42 [Accessed 28 September 2018].

Report From The Commission To The European Parliament, The Council And The European Economic And Social Committee on the application of Directive 2008/52/EC of the European Parliament and of the Council on certain aspects of mediation in civil and commercial matters (COM(2016) 542 final) [online]. Brussels, 26 August. Available from: https://eur-lex.europa.eu/legalcontent/EN/TXT/ ?uri=COM\%3A2016\%3A542\%3AFIN [Accessed 28 September 2018].

Rifkin, J., Millen, J., and Cobb, S., 1991. Toward a new discourse for mediation: A critique of neutrality. Mediation Quarterly [online], 9(2), pp. 151-164. Available from: https://doi.org/10.1002/crq.3900090206 [Accessed 28 September 2018]. 
Rowe, G., and Frewer, L.J., 2000. Public Participation Methods: A Framework for Evaluation. Science, Technology, \& Human Values [online], 25(1), pp. 3-29. Available from: https://doi.org/10.1177\% 2F016224390002500101 [Accessed 28 September 2018].

Saposnek, D.T., 2004. Commentary: The future of the history of family mediation research. Conflict Resolution Quarterly [online], 22(1-2), pp. 37-53. Available from: https://doi.org/10.1002/crq.91 [Accessed 28 September 2018].

Shapira, O., 2016. A Theory of Mediators' Ethics [online]. Cambridge University Press. Available from: https://doi.org/10.1017/CBO9781316534205 [Accessed 28 September 2018].

Shaw, L.A., 2010. Divorce Mediation Outcome Research: A Meta-Analysis. Conflict Resolution Quarterly [online], 27(4), pp. 447-467. Available from: http://psycnet.apa.org/doi/10.1002/crq.20006 [Accessed 28 September 2018].

Silbey, S.S., 1993. Mediation Mythology. Negotiation J ournal [online], 9(4), pp. 349-353. Available from: https://doi.org/10.1111/i.15719979.1993.tb00722.x [Accessed 28 September 2018].

Silbey, S.S., 2002. Emperor's New Clothes: Mediation Mythology and Markets. J ournal of Dispute Resolution [online], 1(11), pp. 171-177. Available from: http://scholarship.law.missouri.edu/jdr/vol2002/iss1/11 [Accessed 28 September 2018].

Stilgoe, J., Owen, R., and Macnaghten, P., 2013. Developing a framework for responsible innovation. Research Policy [online], 42(9), pp. 1568-1580. Available from: https://doi.org/10.1016/j.respol.2013.05.008 [Accessed 28 September 2018].

Taylor, A., 1997. Concepts of neutrality in family mediation: Contexts, ethics, influence, and transformative process. Mediation Quarterly [online], 14(3), pp. 215-236. Available from: https://doi.org/10.1002/crq.3900140306 [Accessed 28 September 2018].

Umbreit, M.S., 2001. The Handbook of Victim Offender Mediation: An Essential Guide for Practice and Research. San Francisco, CA: Jossey-Bass.

Umbreit, M.S., Coates, R.B., and Vos, B., 2004. Victim-Offender Mediation: Three Decades of Practice and Research. Conflict Resolution Quarterly [online], 22(1-2), pp. 279-303. Available from: https://doi.org/10.1002/crq.102 [Accessed 28 September 2018].

Waldman, E., 2011. Mediation Ethics : Cases and Commentaries. San Francisco, CA: Jossey-Bass.

Wall, J., and Kressel, K., 2012. Research on Mediator Style: A Summary and Some Research Suggestions. Negotiation and Conflict Management Research [online], 5(4), pp. 403-421. Available from: https://doi.org/10.1111/j.17504716.2012.00117.x [Accessed 28 September 2018].

Wall, J.A., and Dunne, T.C., 2012. Mediation Research: A Current Review. Negotiation Journal [online], 28(2), pp. 217-244. Available from: https://doi.org/10.1111/j.1571-9979.2012.00336.x [Accessed 28 September 2018].

Wall, J.A., Stark, J.B., and Standifer, R.L., 2001. Mediation a current review and theory development. Journal of Conflict Resolution [online], 45(3), pp. 370391. Available from: https://doi.org/10.1177\%2F0022002701045003006 [Accessed 28 September 2018]. 
Wilson, B., 2010. Mediation Ethics : an Exploration of Four Seminal Texts. Cardozo J ournal of Conflict Resolution [online], 12(1), pp. 119-142. Available from: https://cardozojcr.com/vol12nol/119-142.pdf [Accessed 28 September 2018].

Wing, L., 2009. Mediation and Inequality Reconsidered: Bringing the Discussion to the Table. Conflict Resolution Quarterly [online], 26(4-Special Issue: Colloquy Edition: Challenging the Dominant Paradigms in Alternative Dispute Resolution), pp. 383-404. Available from: https://doi.org/10.1002/crq.240 [Accessed 28 September 2018].

Wiseman, V., and Poitras, J., 2002. Mediation Within a Hierarchical Structure: How Can It Be Done Successfully? Conflict Resolution Quarterly [online], 20(1). Available from: https://doi.org/10.1002/crq.10 [Accessed 28 September 2018].

Wissler, R.L., 2002. Court-Connected Mediation in General Civil Cases: What We Know from Empirical Research. Ohio State J ournal on Dispute Resolution [online], vol. 17, pp. 641-703. Available from: https://ssrn.com/abstract=1723292 [Accessed 28 September 2018].

Wissler, R.L., 2004. The effectiveness of court-connected dispute resolution in civil cases. Conflict Resolution Quarterly [online], 22(1-2. Special Issue: Conflict Resolution in the Field: Assessing the Past, Charting the Future), pp. 55-88. Available from: https://doi.org/10.1002/crq.92 [Accessed 28 September 2018].

Zariski, A., 2010. A Theory Matrix for Mediators. Negotiation J ournal [online], 26(2), pp. 203-235. Available from: https://doi.org/10.1111/j.15719979.2010.00269.x [Accessed 28 September 2018].

Zehr, H., 2004. Commentary: Restorative Justice: Beyond Victim-Offender Mediation. Conflict Resolution Quarterly [online], 22(1-2. Special Issue: Conflict Resolution in the Field: Assessing the Past, Charting the Future), pp. 305-315. Available from: https://doi.org/10.1002/crq. 103 [Accessed 28 September 2018]. 